\title{
Comparing Wind Data at Local Meteorological Stations and in Forested Areas Using Roughness Length and Topographic Exposure Indices
}

\author{
Kamimura, K. \& Saito, S. \\ Keywords: Local meteorological station, roughness length, topographic exposure \\ indices (TOPEX), wind data \\ Abstract: This study evaluates whether wind data at local meteorological \\ stations can be used for studying wind damage in forested areas. \\ Data from four Automated Meteorological Data Acquisition System \\ (AMeDAS) stations and one weather station, located in the northern \\ and southern portions of Hokkaido Island, was compared with wind \\ data collected at flux towers located in the Teshio and Tomakomai \\ regional forests. Anemometers were affixed to the flux towers at a \\ height of $32 \mathrm{~m}$ in Teshio and $40 \mathrm{~m}$ in Tomakomai; thus, the data \\ was assumed to adequately represent wind conditions in a forested \\ area without vegetation effects. Mean wind speed at the AMeDAS \\ stations and weather station sites was converted to extreme wind \\ speed using roughness length on eight directions. This comparison \\ was based on the storm (October to May) and typhoon (August and \\ September) seasons. Subsequently, a distance-limited topographic \\ exposure index (TOPEX) was calculated for all anemometer \\ positions using $1,2,5$, and $10 \mathrm{~km}$ distances from the position. \\ We found that wind at sites with low TOPEX scores and small \\ roughness length could significantly represent wind conditions in \\ nearby forested areas. Wind speeds with high TOPEX scores \\ but small roughness length occasionally showed correlation with \\ conditions at the flux tower. Although additional study is required,
}

Received September 28, 2009; Accepted December 12, 2009 


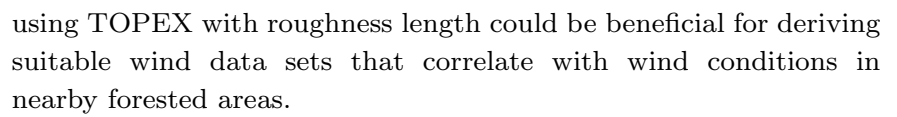

\section{Introduction}

Wind damage is critical for sustainable forest management due to an increasing number of mature forests and climate condition change (Kuboyama and Oka, 2000, Kamimura et al., 2008). There are ongoing efforts to reduce wind damage risk using statistical, empirical, or mechanistic procedures including terrain and/or wind information (Gardiner et al., 2000, Mitchell et al., 2001). However, it is difficult to obtain accurate wind climate data in forests because there are few meteorological stations or weather towers in forested area. Thus, estimation of wind would be required for improving wind damage risk studies.

To estimate wind conditions in forested area, there are several approaches developed using not only geographic but also airflow and boundary-layer knowledge. For instance, Wind Atlas Analysis and Application Program (WAsP) is a common commercial airflow model in Europe. Uchida and Ohya (2002) developed an airflow model, RIAMCOMPACT for complex terrains using large eddy simulation (LES) technique. The Detailed Aspect Method of Scoring (DAMS) yields better wind estimation in valley and moderate slopes mainly based on topographic exposure index (TOPEX) (Suárez et al., 1999). TOPEX is a simple indicator to show how much the target point is exposed by wind, which is the most critical factor to influence windthrow (Ruel et al., 2002). These models are useful for estimating the average wind climate on flat or complex terrain, but not for particular wind conditions such as typhoons and subtropical cyclones.

Wind data in Japan is generally available at local meteorological 
stations including Automated Meteorological Data Acquisition System (AMeDAS) and weather stations managed by the Japan Meteorological Agency. Specifically, AMeDAS is located approximately every 17 $\mathrm{km}$ on Japanese land (Kondo et al., 1991) in or near urban areas. There are several advantages to use these data including easily accessible though internet. In addition, the data at local meteorological stations located near forests are often used in wind damage studies to find out the wind condition at occurring wind damage. However, it remains unclear whether this data accurately represents wind climate in nearby forests. It is also difficult to certify whether it is certainly representing wind climate in the forests. This is because wind varies depending on several factors including terrain, neighbouring conditions, and anemometer height. Therefore, this study aims to find a simple index or procedure to identify whether wind data at local meteorological stations suitably represents the wind conditions in nearby forested areas.

\section{Methods}

Two study sites were selected, one in the Teshio region located in Northern Hokkaido and another in the Tomakomai region in Southern Hokkaido (Fig. 1). Both regions receive strong wind caused by typhoons and subtropical cyclones. Forests in the Tomakomai region suffered from catastrophic wind damage in 2004. We selected the following AMeDAS and meteorological stations located within $25 \mathrm{~km}$ from the towers: Nakagawa and Nakatonbetsu AMeDAS stations in the north and Morino and Shikotsukohan AMeDAS stations and Tomakomai meteorological station in the south of Hokkaido.

Wind speed and direction data were obtained from the websites of the Carbon Balance Monitoring on Terrestrial Ecosystem, National 


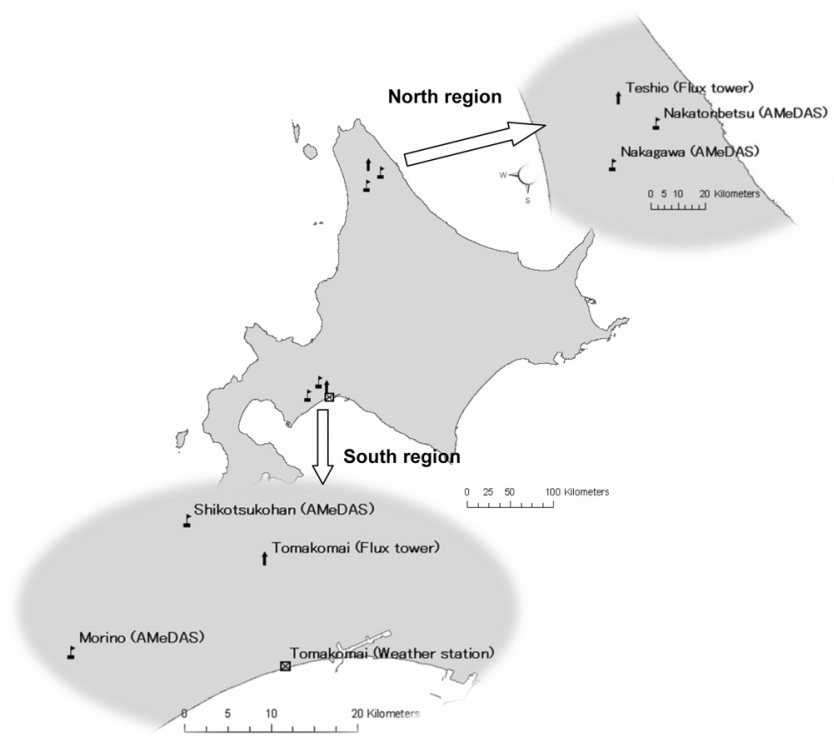

Figure 1. Locations of the AMeDAS, weather station, and flux towers in the Hokkaido Island

Institute for Environmental Studies*1 and of Japan Meteorological Agency $^{* 2}$. Table 1 shows the description of the towers, AMeDAS, and weather station.

In this study, wind data at the flux tower was assumed to correctly observe wind climate in the forests. To avoid vegetation and canopy effects, wind speed and direction measured at $32 \mathrm{~m}$ height on the Teshio tower and those at $42 \mathrm{~m}$ height on the Tomakomai tower were used. Since height and periods of data collection varied among the anemometers, wind data were calibrated using the following steps. First, the data were divided to two seasons. In Japan, strong wind is generally caused

\footnotetext{
${ }^{* 1}$ http://db.cger.nies.go.jp/gem/warm/flux/1forest/index.html

${ }^{* 2}$ http://www.data.jma.go.jp/obd/stats/etrn/index.php
} 
by typhoons or extratropical storms. The highest frequency of strong wind is often observed in winter or in spring, while catastrophic damage is mainly due to typhoon although the frequency is low (Hatakeyama, 1966). Therefore, the data were classified into two seasonal groups; storm (October to May) and typhoon (August to September). All wind data were calculated as the hourly mean speed and degree azimuth, which were then classified to eight directions (N, NE, E, SE, $\mathrm{S}, \mathrm{SW}, \mathrm{W}, \mathrm{NW}$ ). Subsequently, standard deviation (s.d.) of the mean wind speed was calculated for each season and direction. Using s.d. extreme wind speed $\left(U_{\text {extreme }} ; \mathrm{m} / \mathrm{s}\right)$ was converted as:

$$
U_{\text {extreme }}=U_{\text {mean }}+3 \times \text { s.d. }
$$

where $U_{\text {mean }}$ is the mean wind speed $(\mathrm{m} / \mathrm{s})$ and " 3 " is a constant, which can be determined on average due to empirical studies (Kondo, 2000).

Wind speed data at the AMeDAS and the meteorological station were calibrated to compare the data at the towers because the anemometer height of the meteorological station and the AMeDAS varies depending on terrain conditions and/ building height located near stations (Kondo et al., 1991). The speed data were calculated to be the wind speed at the same height as the anemometer heights of the flux tower (32 and $42 \mathrm{~m}$ ) using the following equation (Kondo, 2000).

$$
\text { [2] } \quad U_{t}=U_{a} \times \frac{\log \left(z_{t} / z_{0}\right)}{\log \left(z_{a} / z_{0}\right)}
$$

where $U_{t}$ is the wind speed at the anemometer height on the tower $(\mathrm{m} / \mathrm{s}), U_{a}$ is the wind speed at the anemometer of AMeDAS or the weather station $(\mathrm{m} / \mathrm{s}), z_{t}$ is the anemometer height of the tower $(\mathrm{m})$, $z_{a}$ is the anemometer height of AMeDAS or weather station $(\mathrm{m})$, and $z_{0}$ is the roughness length $(\mathrm{m})$. Unique values of $z_{0}$ in eight directions provided by Kondo et al. (1991) were applied for this calculation (Tab. 2). 
Table 1. Description of the flux towers, AMeDAS, and metrological station used in the analysis

\begin{tabular}{|c|c|c|c|c|}
\hline \multicolumn{4}{|l|}{ North } & \\
\hline Location & Teshio & Nakagawa & Nakatonvetsu & \\
\hline Category & Flux tower & AMeDAS & AMeDAS & \\
\hline Longitude & $142^{\circ} 06^{\prime} \mathrm{E}$ & $142^{\circ} 4.6^{\prime} \mathrm{E}$ & $142^{\circ} 16.8^{\prime} \mathrm{E}$ & \\
\hline Latitude & $45^{\circ} 03^{\prime} \mathrm{N}$ & $44^{\circ} 49.7^{\prime} \mathrm{N}$ & $44^{\circ} 57.9^{\prime} \mathrm{N}$ & \\
\hline $\begin{array}{l}\text { Elevation } \\
(\mathrm{m})\end{array}$ & 70 & 22 & 25 & \\
\hline $\begin{array}{l}\text { Anemometer } \\
\text { height }(\mathrm{m})\end{array}$ & $32,25,21$ & 8 & 10.2 & \\
\hline $\begin{array}{l}\text { Measured } \\
\text { period } \\
\text { (minutes) }\end{array}$ & 30 & 10 & 10 & \\
\hline Vegetation & $\begin{array}{l}18-25(2001- \\
2003)\end{array}$ & Unknown & Unknown & \\
\hline height $(\mathrm{m})$ & $\begin{array}{l}2.5-3.0 \quad(\text { af- } \\
\text { ter 2003) }\end{array}$ & & & \\
\hline $\begin{array}{l}\text { Available } \\
\text { data }\end{array}$ & $2000-2005$ & & & \\
\hline $\begin{array}{l}\text { Distance } \\
\text { from } \\
\text { tower }^{a}(\mathrm{~km})\end{array}$ & 0 & 25 & 17 & \\
\hline \multicolumn{5}{|l|}{ South } \\
\hline Location & Tomakomai & Shikotsukohan & Morino & Tomakomai \\
\hline Category & Flux tower & AMeDAS & AMeDAS & $\begin{array}{l}\text { Metrological } \\
\text { station }\end{array}$ \\
\hline Longitude & $141^{\circ} 31^{\prime} \mathrm{E}$ & $141^{\circ} 24.4 \mathrm{E}$ & $141^{\circ} 14.7^{\prime} \mathrm{E}$ & $141^{\circ} 32.8^{\prime} \mathrm{E}$ \\
\hline Latitude & $42^{\circ} 44^{\prime} \mathrm{N}$ & $42^{\circ} 46.3^{\prime} \mathrm{N}$ & $42^{\circ} 37.9^{\prime} \mathrm{N}$ & $42^{\circ} 37.3^{\prime} \mathrm{N}$ \\
\hline $\begin{array}{l}\text { Elevation } \\
(\mathrm{m})\end{array}$ & $115-140$ & 290 & 170 & 6 \\
\hline Anemometer & $\begin{array}{l}42, \quad 27,22, \\
18,\end{array}$ & 8,4 & 10 & 20.1 \\
\hline height $(\mathrm{m})$ & $14,8,5,0$ & & & \\
\hline $\begin{array}{l}\text { Measured } \\
\text { period } \\
\text { (minutes) }\end{array}$ & 30 & 10 & 10 & 1 \\
\hline $\begin{array}{l}\text { Vegetation } \\
\text { height }(\mathrm{m})\end{array}$ & $18-20$ & Unknown & Unknown & Unknown $^{c}$ \\
\hline $\begin{array}{l}\text { Available } \\
\text { data }\end{array}$ & $\begin{array}{l}2000-2004 \\
2005^{b}\end{array}$ & & & \\
\hline $\begin{array}{l}\text { Distance } \\
\text { from } \\
\text { tower }^{a}(\mathrm{~km})\end{array}$ & 0 & 10 & 25 & 12 \\
\hline
\end{tabular}

Note) ${ }^{a}$ : this is approximately horizontal distance measured using GIS, ${ }^{b}$ : the tower was destroyed caused by typhoon in $2004,{ }^{c}$ : the sea side is spread from SE to SW. 
Table 2. Roughness length $(\mathrm{cm})$ of eight directions at local meteorological stations partly calibrated from Kondo et al. (1991, pp. 184-185) In this study, the directions were moved to 22.5 degrees in anticlockwise to correspond with the wind data

\begin{tabular}{l|cccccccc}
\hline Location & N & NE & E & SE & S & SW & W & NW \\
\hline Nakagawa & 15 & 52 & 68 & 15 & 5 & 5 & 18 & 5 \\
Nakatonbetsu & 95 & 95 & 43 & 29 & 53 & 95 & 91 & 95 \\
Shikotsukohan & 92 & 92 & 92 & 77 & 35 & 18 & 47 & 92 \\
Morino & 22 & 54 & 43 & 46 & 83 & 84 & 87 & 30 \\
Tomakomai & 39 & 99 & 20 & 0.1 & 0.1 & 39 & 51 & 74 \\
\hline
\end{tabular}

Next, distance-limited TOPEX of eight directions was calculated for $1,2,5$, and $10 \mathrm{~km}$ from the anemometer position using $50 \mathrm{~m} \times 50 \mathrm{~m}$ of digital elevation map. The TOPEX score is a parameter representing exposure from wind by measuring the angle from the skyline including the target point to the point on the highest elevation in the eight directions within the limited distance (Wilson, 1984, Quine and White, 1994, Mitchell et al., 2008). The negative scores are counted as zero. The calculation was mainly based on ArcGIS ver. 9.2 (ESRI Co.).

Finally, Pearson's correlation coefficient was obtained for the wind speed at the tower and for the calibrated wind speed at the AMeDAS and the metrological station depending on eight directions. As considering the sensitivity of wind direction at the anemometers, the wind directions of the AMeDAS were assumed to be in the same direction of the tower if the difference of the direction of the AMeDAS was within \pm 45 degrees. For instance, if the wind direction of the AMeDAS is NW and that of the tower is $\mathrm{N}$, then the direction of the AMeDAS would be counted as N. After the calibration, the data would be ex- 
tracted if the directions between the tower and AMeDAS were corresponded. The average ratios of the accepted data to the total data were : Morino AMeDAS (66\%), Nakatonbetu AMeDAS (70\%), Nakatonbetsu AMeDAS (71\%), Shikotsu AMeDAS (50\%), and Tomakomai meteorological station (73\%). Consequently, the results and TOPEX scores were compared to find relationship between wind speed measurements and terrain exposure by wind.

\section{Results}

\subsection{North region}

Table 3 shows the correlation of the extreme wind speed between the flux towers and the AMeDAS and weather station. In storm season, $U_{\text {extreme }}$ at Nakagawa AMeDAS, in particular from the SW, was significantly correlated to that at the flux Tower (Teshio). $U_{\text {extreme }}$ from the $\mathrm{E}$ and NW showed a relatively significant relationship. In typhoon season $U_{\text {extreme }}$ from the $\mathrm{SW}$ and $\mathrm{W}$ at Nakagawa AMeDAS seemed to be correlated to that at the tower. In terms of Nakatonbetsu AMeDAS, $U_{\text {extreme }}$ from the $\mathrm{N}$ was most significant during storm season, while $U_{\text {extreme }}$ from the SE showed the best correlation during typhoon season. At both AMeDAS, $U_{\text {extreme }}$ from the SW was often observed.

Total TOPEX scores at all anemometer positions increased more than twice between 1 and $10 \mathrm{~km}$ distance (Tab. 4).

More specifically, the TOPEX scores of the Nakagawa AMeDAS were approximately twice and those of the Nakatonbetsu AMeDAS two to four times greater than those of the flux tower. For the Nakagawa AMeDAS, there were no shelters in the southern side (E to W) within $2 \mathrm{~km}$ from the anemometer (Fig. 2). In addition, strong wind was observed particularly from the SW partly due to low shelter effects. At the Nakatonbetsu AMeDAS, almost all directions were sheltered within 1 to $2 \mathrm{~km}$ except for the NE, although poor correlation was found in 

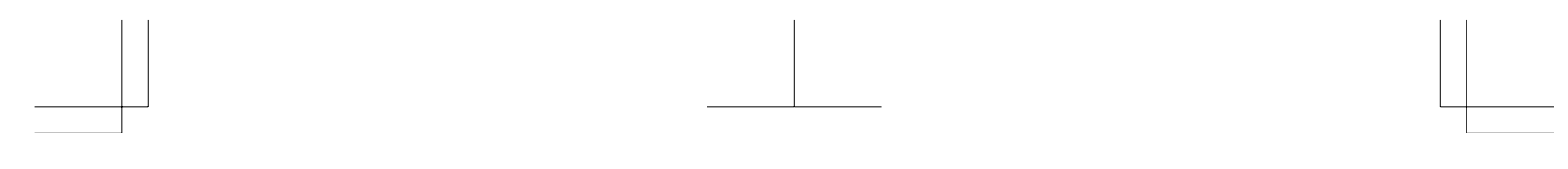

Comparing Wind Data Using Roughness Length and TOPEX
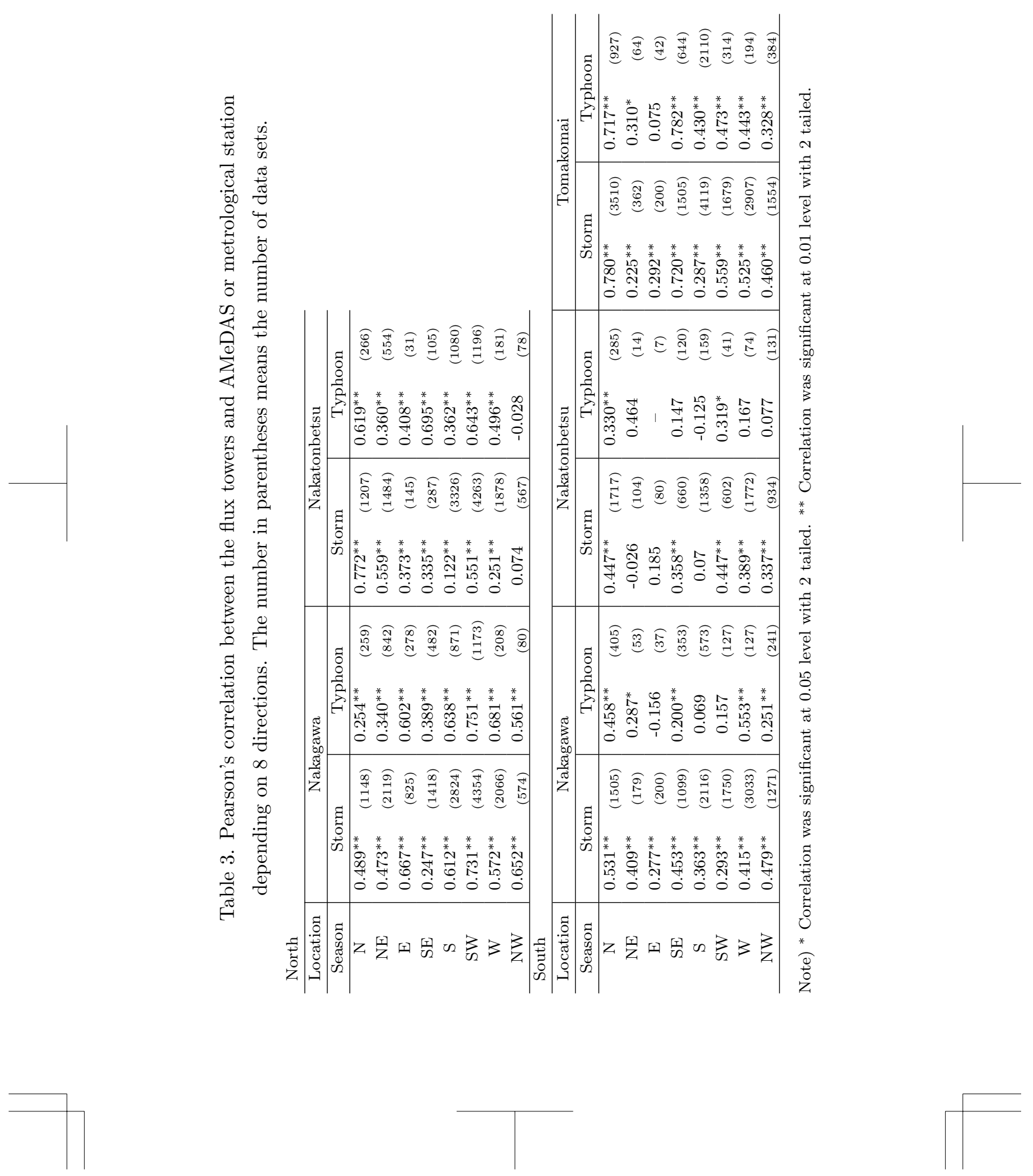

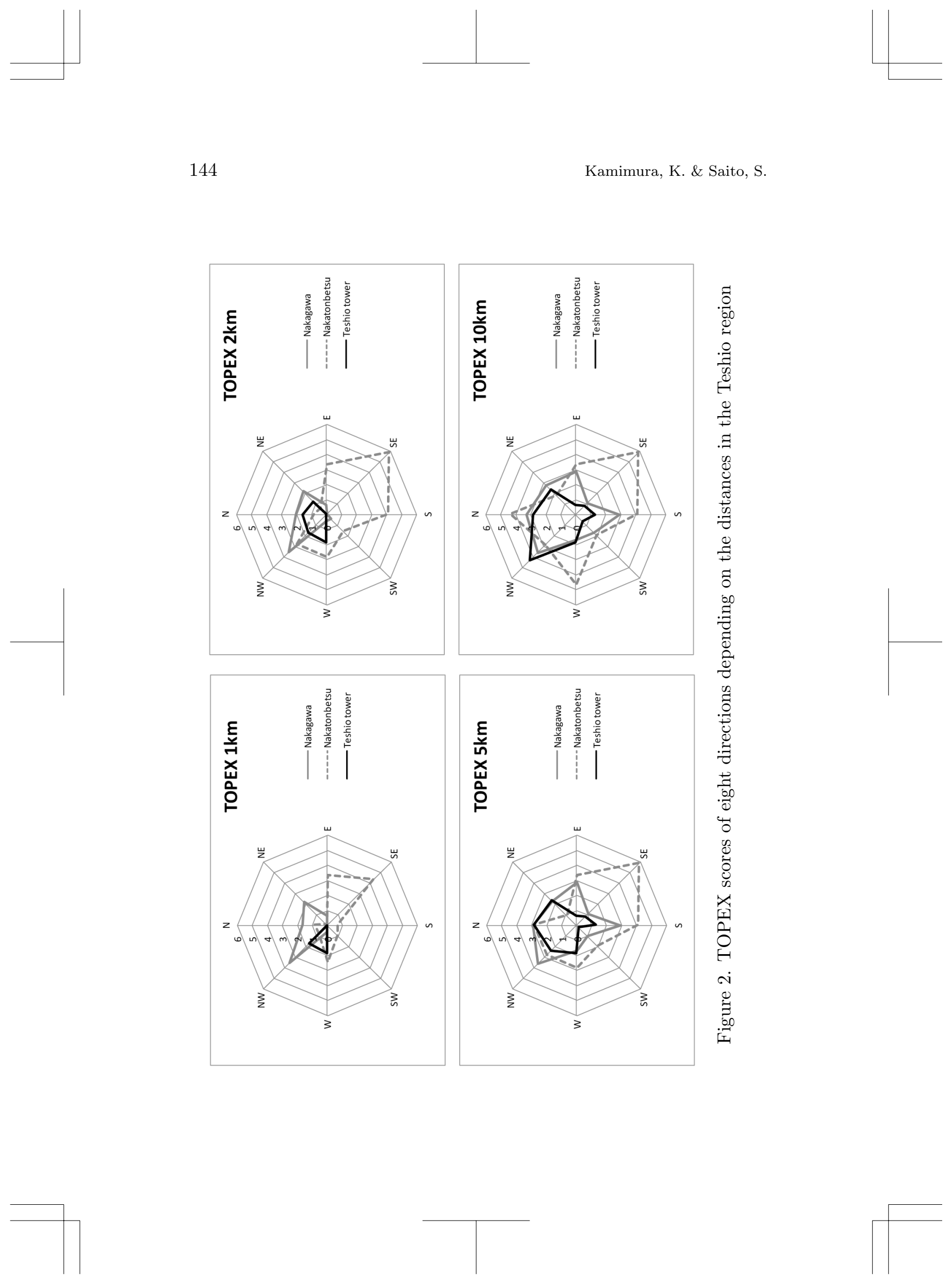
Table 4. Total TOPEX scores of 8 directions depending on 4 distances: $1,2,5$, and $10 \mathrm{~km}$ from the tower, AMeDAS and meteorological station

\begin{tabular}{c|cccc}
\hline TOPEX & $1 \mathrm{~km}$ & $2 \mathrm{~km}$ & $5 \mathrm{~km}$ & $10 \mathrm{~km}$ \\
\hline Teshio (tower) & 3.59 & 6.37 & 12.32 & 14.66 \\
Nakagawa & 8.46 & 9.30 & 18.27 & 19.83 \\
Nakatonbetsu & 13.48 & 21.91 & 24.67 & 28.97 \\
Tomakomai (tower) & 2.58 & 2.97 & 3.38 & 4.58 \\
Shikotsukohan & 69.11 & 70.62 & 70.61 & 71.28 \\
Morino & 62.95 & 65.68 & 66.66 & 66.97 \\
Tomakomai & 0.45 & 1.82 & 5.71 & 4.66 \\
\hline
\end{tabular}

wind speed from NE (see Fig. 2 and Tab. 3). Wind from the N shows the best correlation in storm season despite of a shelter within $1 \mathrm{~km}$ from the AMeDAS. At the Teshio tower, the TOPEX scores also increasing, and they were close to those of the Nakatonbetsu AMeDAS within $5 \mathrm{~km}$. Wind from the SE also showed better correlation than the wind from oth er directions. Although the TOPEX score of the SE was always high, the roughness length was the smallest among those in other directions. This intended that wind turbulence was stable compared to the wind from other direction (Kondo et al., 1991).

\subsection{South region}

At the Shikotsukohan AMeDAS, a significant relationship with the tower was found in the $\mathrm{N}$ during two seasons. On the other hand, $U_{\text {extreme }}$ from the $\mathrm{N}$ and $\mathrm{SE}$ at the Tomakomai weather station was significantly correlated to $U_{\text {extreme }}$ at the Tomakomai tower. The wind blew most often from the $\mathrm{S}$ for both seasons at the Tomakomai AMeDAS (Tab. 3) because of effects from the ocean. The reason for the poor correlation at the Shikotsukohan and Morino AMeDAS stati- 

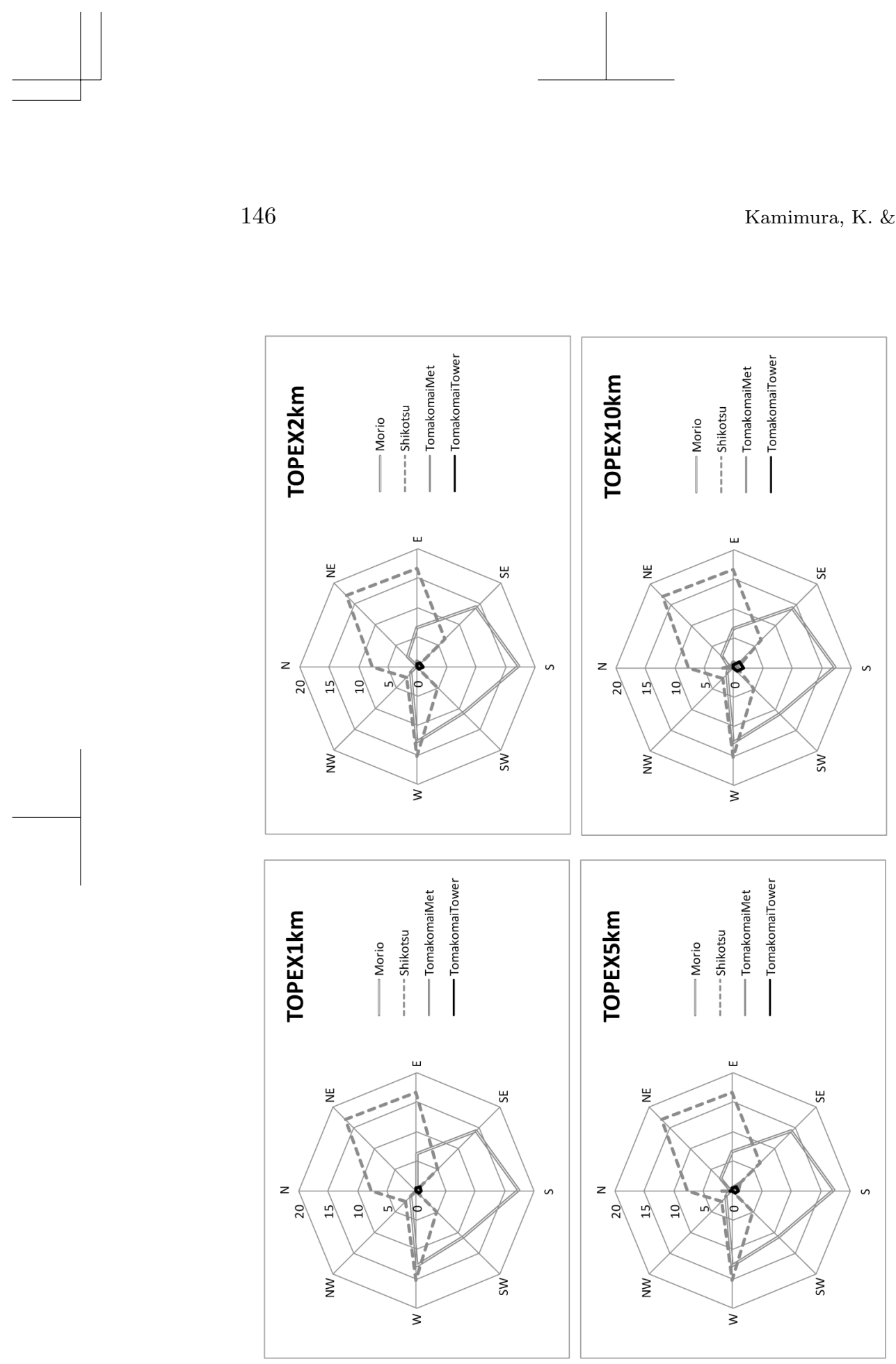

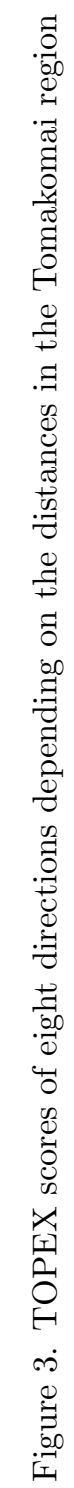

ons is the strong shelter effects caused by hill located near the anemometers. Total TOPEX scores of the Shikotsukohan and Morino AMeDAS stations were approximately 14 to 27 times greater than those of the tower, while the scores of the Tomakomai meteorological station were not considerably different from those of the flux tower (Tab. 4). In addition, the total scores of the Shikotsukohan and Morino AMeDAS stations were high within $1 \mathrm{~km}$ and did not change within $10 \mathrm{~km}$. This indicates that there are very close and high shelters to the AMeDAS stations. Figure 3 shows more detailed terrain condition using the TOPEX scores of eight directions. Few differences were found between the Tomakomai weather station and the tower in all directions. There is also a lake in the NW of the Shikotsukohan AMeDAS. This exposed area could lead to better correlation of wind from the $\mathrm{W}, \mathrm{NW}$, and $\mathrm{N}$ in both seasons except wind from the NW during typhoon season.

To sum up, wind with low TOPEX scores and low roughness length tended to suitably represent $U_{\text {extreme }}$ in forested areas located within $25 \mathrm{~km}$ from the local meteorological sites. Wind with high TOPEX scores but low roughness length also showed better correlation to the wind in the forests, but only if there were no high shelters located near anemometer positions, i.e. low TOPEX scores within 1 to $2 \mathrm{~km}$ distance were required (See Tab. 2, Fig. 2 and 3).

\section{Discussion and Conclusion}

Wind data at the local meteorological stations were compared with that at the flux towers located in the forested areas to determine whether the data were statistically related to the wind condition in the nearby forests. We found that wind data at the sites with low TOPEX scores and small roughness length correlated to the wind in the nearby forested areas. This finding allows wind speed data at different anemometers to be integrated in order to obtain better data-sets of 
wind conditions in forested areas. In addition, our study clarifies that distance from forested areas is not always the key to finding anemometers associated with wind conditions in forested areas. However, several disagreements were also found using the relationship between TOPEX and wind climate, perhaps caused by the neighbouring environment of the anemometer and limitations of TOPEX.

There are several problems with measuring wind, especially at AMeDAS. For instance, the AMeDAS location or anemometer height occasionally changes due to changes in neighbouring environment. For instance, AMeDAS tends to be moved to the other place if it suffers from any interruption due to construction of new buildings or change of tree height. In addition, since most weather stations and AMeDAS were generally located in the centre of town with various anemometer heights, it is difficult to observe surface wind flow (Mitsuda, 1997). In this study, we calculated wind speed at the same height of the tower anemometer using roughness length provided by Kondo et al. (1991). However, roughness length might change due to new buildings constructed around the anemometers. Some of the anemometer heights have been also changed. Thus, it is necessary to find information on neighbouring environments before using wind climate data for nearby forests.

Distance-limited TOPEX provides a useful overview of wind exposure for site terrain conditions, which one of the keys of wind condition. TOPEX is also easily calculated using GIS. With these advantages, TOPEX can be applied to predict local wind estimation by using airflow models such as the mesoscale numerical weather prediction model (Mitchell et al., 2008). However, our study shows that TOPEX cannot be the only indicator to select wind data for nearby forested area. This is because TOPEX itself does not account for environmental conditions such as roughness length. Sites with less exposure are more likely to 
receive less extreme wind. On the other hand, if the site has large roughness length but low mean wind speed, then extreme wind speed tends to be accelerated caused by strong turbulence during unstable airflow condition (Kondo and Kuwagata, 1984). In addition, Turnipseed et al. (2003) points out that forest canopy is more critical than terrain complexity. Airflow above canopy is also strongly associated with stem density (Kondo and Yamazawa, 1983). Therefore, additional information, in particular, roughness length is required to improve wind data selection using TOPEX.

It is challenging to find appropriate wind data for estimating wind conditions in forested area. Nevertheless, using a simple procedure or index would be beneficial. Further studies are required to develop procedures for finding suitable wind data sets at local meteorological stations associated with wind climate in forested areas.

\section{Acknowledgement}

The authors wish to acknowledge Prof. Stephen J. Mitchell and Mr. Arnold Moy, the University of British Colombia, who have been developing wind damage study and created wonderful computer script to calculate distance-limited TOPEX. The wind data at the flux towers in Teshio and Tomakomai was provided by Carbon Balance Monitoring on Terrestrial Ecosystem, National Institute for Environmental Studies.

\section{References}

Gardiner, B., Peltola, H. and Kellomaki, S. (2000) Comparison of two models for predicting the critical wind speeds required to damage coniferous trees, Ecol. Model. 129: 1-23.

Hatakeyama, H. (1966) Meteorological Disaster, Kyoritsu Shuppan, 446p. (in Japanese).

Kamimura, K., Gardiner, B., Kato, A., Hiroshima, T. and Shiraishi, 
N. (2008) Developing a decision support approach to reduce wind damage risk: A case study on sugi (Cryptomeria japonica (L.f.) D. Don) forests in Japan, Forestry 81: 429-445.

Kondo, J. (2000) Atmospheric Science near Ground Surface, University of Tokyo Press, 336p. (in Japanese).

Kondo, J. and Kuwagata, T. (1984) On the unusual dryness and strong wind weather which caused a larger number of forest fires over the Tohoku district on 27 April 1984 (Part 2), Tenki 31: 37-52 (in Japanese)

Kondo, J., Kuwagata, T. and Nakazono, M. (1991) Method of estimating the representative wind speed over land surface, J. JSNDS 10: 171-185 (in Japanese).

Kondo, J. and Yamazawa, H. (1983) Surface wind speed and aerodynamic roughness over complex ground surface, Tenki 30: 553-561 (in Japanese).

Kuboyama, H. and Oka, H. (2000) Climate risks and age-related damage probabilities - effects on the economically optimal rotation length for forest stand management in Japan, Silv. Fenn. 34: $155-166$.

Mitchell, S. J., Hailemariam, T. and Kulis, Y. (2001) Empirical modeling of cutblock edge windthrow risk on Vancouver Island, Canada, using stand level information, Forest Ecol. Manag. 154: 117-130.

Mitchell, S. J., Lanquaye-Opoku, N., Modzelewski, H., Stulb, P., Jackson, P., Murphy, B. and Ruel, J. C. (2008) Comparison of wind speeds obtained using numerical weather prediction models and topographic exposure indices for predicting windthrow in mountainous terrain, Forest Ecol. Manag. 254: 193-204.

Mitsuda, Y. (1997) Prediction of typhoon damages, DPRI Annuals 40: 47-61 (in Japanese).

Quine, C. P. and White, I. M. S. (1994) Using the relationship between 
rate of tatter and topographic variables to predict site windiness in Upland Britain, Forestry 67: 245-256.

Ruel, J. C., Mitchell, S. J. and Dornier, M. (2002) A GIS based approach to map wind exposure for windthrow hazard rating, North. J. Appl. Forestry 19: 183-187.

Suárez, J. C., Gardiner, B. A. and Quine, C. P. (1999) A comparison of three methods for predicting wind speeds in complex forested terrain, Meteorol. Appl. 6: 329-342.

Turnipseed, A. A., Anderson, D. E., Blanken, P. D., Baugh, W. M. and Monson, R. K. (2003) Airflows and turbulent flux measurements in mountainous terrain, Part 1. Canopy and local effects, Forest Ecol. Manag. 119: 1-21.

Uchida, T. and Ohya, Y. (2002) Numerical simulation on wind fields over complex terrain using nested grids, J. Wind Eng. 92: 134-144 (in Japanese).

Wilson, J. D. (1984) Determining a topex score, Scot. Forestry 38: 251-256. 


\title{
粗度長および被覆度指標を利用した気象観測所と森 林地帯における風速データの比較
}

\author{
上村 佳奈・齊藤 哲
}

要約:

本研究では, 地域気象観測所で観測された風況データが, 近隣の森林地带に おける風害研究に使用可能であるかを評価した. 北海道北部 (天塩地域) と 南部 (苫小牧地域)に扔いて, 4 カ所の地域気象観測システム (アメダス) 1 力所の測候所での風況データ, および森林地带に設置されている 2 本のフ ラックスタワーで観測されたデータを比較した. フラックスタワーには最上 部に風速計 (天塩では地上 $32 \mathrm{~m}$, 苫小牧では $40 \mathrm{~m}$ ) があり, 樹冠部より高い 位置にあることから, 森林上部の風況を正確に観測していると見なした.さ らに, AMeDAS 等のすべての平均風速を, 8 方向の粗度を用いて, 1 時間当 たりの瞬間風速に変換した. 比較については, データを温帯低気圧時期 $(10$ 月から 5 月) と台風時期 (8月扰よび 9 月) に分割して行った. 次に, 距離 制限をした風に対する露出度指標 (TOPEX) を，風速計位置から $1,2,5$, $10 \mathrm{~km}$ まで 8 方向について計算した. 結果として, TOPEX と粗度の両方が 低い場合は, 気象観測所の風速データは近隣の森林地带における風速と相関 関係があった. TOPEX が高くても, 粗度が低い場合, ある程度の関係が確 認された. 今後さらに研究が必要ではあるが, TOPEX と粗度の関係から, 近隣の森林地域における風況と関係があるデータを選択することは可能であ ると考えられた。

キーワード: 風況データ, 露出度指標 (TOPEX), 粗度長, 地域気象観測所 